原著

\title{
コクサッキーウイルス $\mathrm{B}$ 群の血清疫学的研究 岐阜県に打る抗体保有率の推移
}

\author{
岐阜県衛生研究所 \\ 渡辺実野田伸司山田不二造
}

（昭和 57 年 2 月 22 日受付）

（昭和57年 6 月 8 日受理）

Key words: Coxsackie B Viruses, NT Antibody, Age Distribution, Annual Alteration

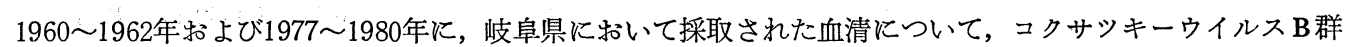
に対する中和抗体保有率の調査を行い，血清疫学的検討を加えた.

1977〜1980年には，1960１962年に比較して，0２歳には抗体保有率の低下が認められたが，3〜10歳に は著明な抗体保有率の上昇が認められた。11歳以上の年齢層には，抗体保有率の変化は，ほとんど認められな かった。

型別には，1 型抗体は，1960１962年の 0 2 歳には22\%の保有率が認められるが，1977年～1980年の同年 齢層には，抗体保有者はほとんど認められず，1 型ウイルスの年次的な消長の大きさが推測される４ 型抗体 は, いずれの年次に执いても各型中, 最も高い保有率が認められ，4型ウイルスの常在性の強さが示された。 5 型抗体は，いずれの年次に损いても 6 15歳に保有率のピークがみられ，成人層には，著明な保有率の低下 が認められた。

5 歳以下で，抗体を全く保有しないものの比率は，1960～1962年には，0歳の50\%から 5 歳の $20 \%$ までゆ るやかに減少するのに対し，1977１980年には，0歳の100\%から 5 歳の0\%をで，急激な下降が認められ た.

\section{緒言}

1960～1962年の岐阜県に括ける，コクサッキー ウイルス B 群 (以下 Cox. B ) $1 \sim 5$ 型の血清疫 学的調査 ${ }^{1)}$ にれれば，県下各地域の全ての年齢層 に抗体の保有が認められ，当時から Cox. B の岐 阜県に括ける広い分布が推定されていた. 現在に

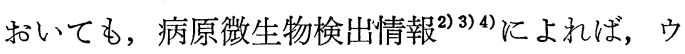
イルス型により年次的消長の違いはみられるが，

別冊請求先：（广 500）岐阜市野一色 4-6-3 岐阜県衛生研究所 渡辺 実
Cox. B が全国的に，ほぼ常在性に近い分布をし ていることが示されている.

一方，厚生省の統計 ${ }^{5)}$ とよば， 1960～1980年 の間に, 消化器系伝染病の発生は激減し, 同じ翼 口型の経口感染によって成立する A 型肝炎 ${ }^{6)}$ ，お

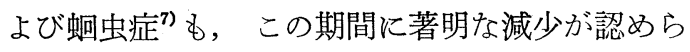
れる。

Cox. B の感染経路は, 糞便を介しての経口感 染が主であると言われている8 が，ポリオウイル スで行われたような感染成立の条件に関する詳細 な研究はみられない.今回は1960～1962年および 
1977〜1980年に，岐阜県下で得られた血清につい て, Cox. B 抗体保有率の推移を調査し, 岐阜県 に和ける Cox. B 感染の実態について検討を行っ たので報告する.

\section{材料および方法}

1. 被検血清

岐阜県下各地に拈いて，1960～1962年抢よび19 77〜1980年に, 各種の感染症の感受性調査の目的 で健康者から採取された血清を使用した。

2. ウイルス

Cox. B $1 \sim 5$ 型を対象とし， ウイルス株は， 過去の報告1)に扮いて使用したものと同一の株を 使用した。

\section{3. 中和試験}

過去の報告 ${ }^{1)}$ 準じて行った。血清は10倍希釈 を用いた。

4. 年次別抗体保有率の比較

1960〜1962年の血清については，地域別および 年齢別分布調查成績として過去に報告したが，今 回は，岐阜県を 1 地区と見なして集計し，1977〜 1980年の血清について得られた成績との間で抗体 保有率の比較を行った。

\section{成 績}

中和抗体保有率の年齢別和よび年次別の成績を Table 1 に示した. 1960～1962年には，各型とも
10歳までは抗体保有率の上昇はゆるやかであり， 各型の抗体保有率の平均は， $0 \sim 2$ 歳の $15.2 \%$ か ら 6〜10歳の $28.5 \%$ と，2 倍以下の上昇率に止ま った. 1977〜1980年には，同年齢層に拉ける抗体 保有率の上昇は急激であり，0２歳の $11.8 \%$ か ら 6〜10歳の $52.7 \%$ と，4.5倍の上昇率が認めら れた。いずれの年次に拈いても，11〜15歳の年齢 層に最高の抗体保有率が認められ，各型の抗体保 有率の平均は，1960～1962年には62.0\%，1977〜 1980年には $56.2 \%$ であった。16歳以上では，どの 年次でも抗体保有率はやや低下する傾向が認めら れた. 上記の成績は，Fig. 1 にも示したが，3〜 10歳の年路層に怙ける抗体保有率が，1977〜1980 年には1960～1962年に比較して著明な上昇が認め

Fig. 1 Average Positive Rate of Cox. B (1 5) Antibodies by Age in 1960-62 and 1977-80

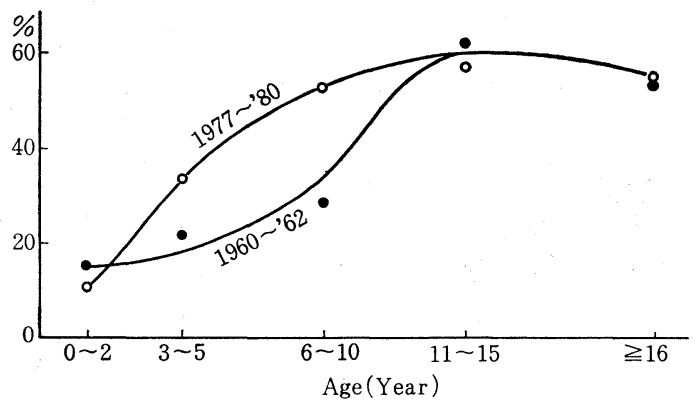

Table 1 Age Distribution of Cox. B (1 5) Antibodies in 1960-62 and 1977-80

\begin{tabular}{|c|c|c|c|c|c|c|c|c|c|c|c|c|c|}
\hline \multirow{2}{*}{ 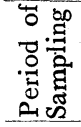 } & \multirow{2}{*}{$\begin{array}{c}\text { Age } \\
\text { (Year) }\end{array}$} & \multirow{2}{*}{ No. Sera } & \multicolumn{2}{|c|}{$B-1$} & \multicolumn{2}{|c|}{$B-2$} & \multicolumn{2}{|c|}{$B-3$} & \multicolumn{2}{|c|}{$B-4$} & \multicolumn{2}{|c|}{$\mathrm{B}-5$} & \multirow{2}{*}{$\frac{B-1 \sim 5}{\%}$} \\
\hline & & & Pos. & $\%$ & Pos. & $\%$ & Pos. & $\%$ & Pos. & $\%$ & Pos. & $\%$ & \\
\hline \multirow{6}{*}{ 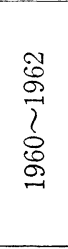 } & $0 \sim 2$ & 63 & 14 & 22 & 14 & 22 & 4 & 6 & 6 & 10 & 10 & 16 & 15.2 \\
\hline & $3 \sim 5$ & 61 & 16 & 26 & 19 & 31 & 7 & 11 & 15 & 25 & 12 & 20 & 22.6 \\
\hline & $6 \sim 10$ & 47 & 9 & 19 & 15 & 32 & 12 & 26 & 18 & 38 & 13 & 28 & 28.5 \\
\hline & $11 \sim 15$ & 20 & 14 & 70 & 13 & 65 & 12 & 60 & 17 & 85 & 6 & 30 & 62.0 \\
\hline & $\geqq 16$ & 26 & 15 & 55 & 16 & 62 & 17 & 65 & 19 & 73 & 3 & 12 & 53.9 \\
\hline & Totals & 217 & 67 & 30.7 & 67 & 30.7 & 52 & 23.9 & 75 & 34.4 & 44 & 20.2 & 28.1 \\
\hline \multirow{6}{*}{ 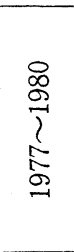 } & $0 \sim 2$ & 49 & 1 & 2 & 5 & 10 & 5 & 10 & 11 & 23 & 7 & 14 & 11.8 \\
\hline & $3 \sim 5$ & 66 & 11 & 17 & 24 & 36 & 19 & 29 & 33 & 50 & 23 & 35 & 33.3 \\
\hline & $6 \sim 10$ & 33 & 11 & 33 & 18 & 55 & 15 & 46 & 23 & 70 & 20 & 61 & 52.7 \\
\hline & $11 \sim 15$ & 37 & 20 & 54 & 18 & 49 & 22 & 60 & 30 & 81 & 14 & 38 & 56.2 \\
\hline & $\geqq 16$ & 27 & 12 & 44 & 17 & 63 & 16 & 59 & 22 & 82 & 6 & 22 & 54.1 \\
\hline & Totals & 212 & 55 & 25.9 & 82 & 38.7 & 77 & 36.3 & 119 & 56.1 & 70 & 33.0 & 38.0 \\
\hline
\end{tabular}




\section{られる。}

型別には, 1 型抗体は 0 ～ 2 歳の年㱓層には, 1960〜1962年には22\%の保有率が認められたが， 1977〜1980年には，49例中 1 例， $2 \%$ の保有率で あった.また $3 〜 5$ 歳の年秢層においても，1977 〜1980年には $2,3 ， 4$ および 5 型抗体の保有率 はすべて1960～1962年より高率であるが， 1 型抗 体のみは1977〜1980年が低率であった． 4 型抗体 は1960～1962年には 6 歳以上，1977～1980年には 3 歳以上の年齢層では, 他の全ての型よりも保有 率は高く, 11 15歳の年齢層では, いずれも年次 に扔いても80\%以上の保有率が認められた。 5 型 抗体は，1960～1962年には 6 10歳の年齢層に, 1977〜1980年には11〜15歳の年路層に保有率のピ 一クが認められたが，16歳以上の年齢層では，両 年次とも保有率はそれぞれ $1 / 2$ 以下に低下するの が認められた。

5 歳以下の乳幼児について, 各年齢ごとに, 各 個体が保有する抗体の型の数の分布を Fig. 2 に 示した. 1960〜1962年には, 0 歳 ( $6 〜 12$ 月) の 半数以上の 児童に 抗体の保有が 認められたが, 1977〜 1980年には，9例中，抗体保有者は 1 例も 認められなかった. 1 歳では保有抗体数の平均 は，1960～1962年は0.64，1977～1980年は0.56， 2 歳では，それぞれ0.88拈よび0.94とほぼ同数の 保有が認められた。しかし 3 歳では1960〜1962年 には1.0，1977〜1980年には1.22，4歳ではそれ ぞれ1.16拉よび1.58，5歳では1.28および2.16

Fig. 2 Number of Antibodies in Individual Infants against Coxsackie B $(1 \sim 5)$ Viruses in 1960-62 and $1977-80$.

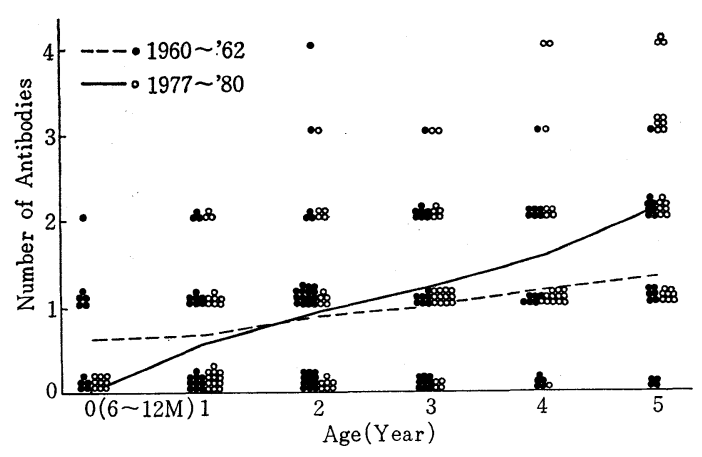

Fig. 3 Rate of Infants Having No Antibodies against Cox-B (1 5) Viruses in 1960-62 and 1977-80

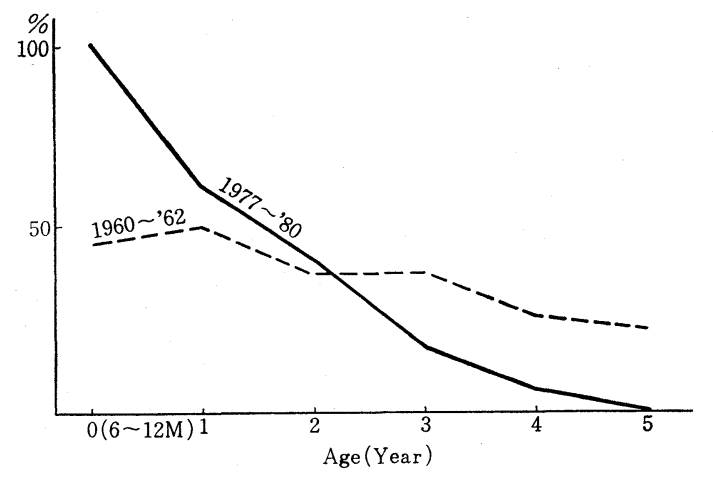

と1977〜1980年に怙ける保有抗体数が加齢と共に 1960〜1962年より増加する傾向が認められた。 た1960～1962年には，4種以上の型の抗体を保有 するものは 2 歳に 1 例認められたが，1977〜1980 年には, 4 歳に 2 例 た.

$0 \sim 5$ 歳の年齢層で, Cox. B の $1 \sim 5$ 型全て の抗体を保有しないものの 各年蹂ごとの 比率を Fig. 3 に示した。1960～1962年には，0歳，46 $\%, 1$ 歳, $50 \%, 2$ 歳, 38\%，4歳，26\%，扣よ び 5 歳，21\%とゆるやかな減少率が認められた。 これに対し，1977〜1980年に拈いては，0歳， $100 \%, 1$ 歳, $57 \%, 2$ 歳, $50 \%, 3$ 歳, $17 \%$, 4 歳， $6 \%$ ，および 5 歳，0\%と急激に減少する 傾向が示された.

\section{考 察}

この20年間に拈ける Cox. B $1 \sim 5$ 型抗体の年 齢別保有率について，最も特街的と思われるの は，3〜10歳の年㱓層に括ける抗体保有率の著明 な上昇，扣よび 5 歳以下の年龆層に和ける $1 \sim 5$ 型抗体を全く保有しない児童の加龄による急速な 減少である.これらの現象は, 岐阜県に拈いて, Cox. B の感染時期が年龄的に早まっていること を推測させる．乙かし，0歳児では1960～1962年 には, 半数以上のものに抗体の保有が認められた が，1977〜1980年には 1 例も認められず，乳児期 には，むしろ感染機会が減少しているよらに思わ 
れる.

抗体保有率のピークは，いずれの年次において も11～15歳の年齢層に認められ，1～5 型抗体保 有率の平均值は $60 \%$ 前後，16歳以上では $54 \%$ であ った。ポリオウイルス抗体の場合は，過去の岐阜 県に括ける調查では同年齢層の抗体保有率は, 各 型とも80〜90\%を示して拈り，Cox. B の地域的 な飽和度はポリオウイルスに比較して低いように 思われる。

人の粪便を介した経口感染によって成立する細 菌，ウイルスおよび寄生虫感染症は，この20年間 に激減している. Cox. B も飛沫を介しての気道 感染もあるが，糞便を介しての経口感染が主であ ると言われなな゙ら，本調查の成績からは，他の 経口感染症に見られるような減少傾向は認められ なかった，赤痢，腸チフスおよび蜔虫症等は感染 源対策，ポリオについては感受性者対策の効果が 大きいと言われるが， A 型肝炎のように，特にい ずれの対策もとられていない感染症の減少には衛 生環境の改善，即ち感染経路対策の向上に負う所 がきわめて大きいと言われている ${ }^{10)}$. 同様に特異 的な対策のとられていない Cox. B 感染が経口 感染を主体とするものであれば，抗体保有率の推 移からみた本ウイルス感染の増加傾向は，一つの 矛盾を示するのでもある。 Kibrick ${ }^{11}$ は Cox. B によるいくつかの上気道感染の流行例を紹介し， Chanock \& Parrot ${ }^{12)}$ は小坚科領域に打将る Cox. $\mathrm{B}$ 感染症の中, 気道性疾患からのウイルス分離が 非気道性の疾患より，やや高率である成績を示し ている. 病原微生物検出情報2) 3) 4) 飞よっても， Cox. B 感染症は, 不顕性感染を除くと, その大 半は上気道炎である. Cox. B 感染に拈いて気道 感染の役割は，これまで言われている以上に大き いのではないかと思われる。

岐阜県の1960年に和ける，3〜 5 歳児の幼稚園 抢よび保育園の入園率は，83,000人中 27,000 人， $32 \%$ であったが，1980年には，94,000人中 83,000
人， $88 \%$ に上昇した．大谷は，各種の呼吸器感染 症が今後集団社会生活の傾向が強まるにつれて問 題が増加すると予想している ${ }^{13)}$ 。前述の如く, Cox. B の感染経路として 気道感染の役割が大き いとすれば，岐阜県に和ける幼児の集団化の促進 が，Cox. B 感染の機会を高めている原因の一つ とも考光られる。

今後は，血清提供者の生活環境条件を考慮した ウイルス検索と併行した血清疫学的調査が必要と 思われる。

\section{文献}

1) 渡辺 実, 井上裕正：B 群コクサッキーウルス の血清疫学的研究一岐阜県に打将当中和抗体 の 分布. 日本公衛誌, $11: 8,1-3,1964$.

2）病原微生物検出情報: 第 1 号, 8, 1980 .

3）病原微生物検出情報：第11号，14-15，1981.

4）病原微生物検出情報：第22号，16-18，1981.

5）厚生省大臣官房統計情報部：伝染病統計，食中 毒統計，昭和55年，16-17，1980。

6）森次保雄，鈴木 宏，市田文弘，小田正幸，高 橋善弥太, 志方俊夫, 織田敏次: 免疫粘着血 球凝集反応による $\mathrm{A}$ 型肝炎の 血清䛦断. 肝臓, $17: 223-228,1976$.

7）児玉 威：乙尿中の病原微生物の 消長. 用水 之廃水, $20: 1153-1158,1978$.

8) 渡辺悌吉：コクサッキーウイルス感染症. 内 科シリーズ 33, かぜ症候群のすべて。160一 $169,1978$.

9）渡辺 実, 谷本浩一, 井上裕正: ポリオの血清 疫学的研究一岐皁県飞打けるポリオウイルス の侵いん度について。ウイルス，10:88一-93， 1960.

10) 志方俊夫：A 型肝炎研究の 現状. 臨床とウイ ルス, $6: 11-16,1978$.

11) Kibrick, S.: Current status of Coxsackie and Echo viruses in human disease. Progr. Med. Virol., 6: 27-70, 1964.

12) Chanock, R.M. \& Parrott, R.M.: Acute respiratory disease in infancy and childhood; Present understanding and prospects for prevention. Pedeatrics, 36: 21—39, 1965.

13）大谷 明：ウイルス感染症の变遷と最近の動 向. 内科 Mook. 11: 6-13, 1980. 


\section{Seroepidemic Survey of Coxsackie B Viruses in Gifu Prefecture, \\ Japan, 1960-1980 \\ Minoru WATANABE, Nobuji NODA \& Fujizo YAMADA \\ Gifu Prefectural Institute of Public Health}

Survey of Antibody of Coxsackie B viruses was carried out on sera obtained in 1960-62 and 1977-80 in Gifu prefecture, Japan.

Positive rates of antibodies in infants aged 3-10 years in 1977-80 were much higher than those in infants in 1960-62. No remarkable differences in positive rates in infants aged over 11 years, between these periods, were recognized.

In 1960-62, 22\% of children aged five years were still seronegative against 5 types of Coxsackie B viruses, whereas in 1977-80 all children had one or more types of antibody by the age of five years.

It seems likely that from these data the aquisition of Coxsackie B virus infection became earier in childhood in these two decades in Gifu prefecture. 